University of Michigan Law School

University of Michigan Law School Scholarship Repository

Law \& Economics Working Papers

$1-1-2014$

\title{
The Devil in the Details: Reflections on the Tax Reform Act of 2014
}

Reuven S. Avi-Yonah

University of Michigan Law School, aviyonah@umich.edu

Follow this and additional works at: https://repository.law.umich.edu/law_econ_current

Part of the Tax Law Commons

\section{Working Paper Citation}

Avi-Yonah, Reuven S., "The Devil in the Details: Reflections on the Tax Reform Act of 2014" (2014). Law \& Economics Working Papers. 99.

https://repository.law.umich.edu/law_econ_current/99

This Article is brought to you for free and open access by University of Michigan Law School Scholarship Repository. It has been accepted for inclusion in Law \& Economics Working Papers by an authorized administrator of University of Michigan Law School Scholarship Repository. For more information, please contact mlaw.repository@umich.edu. 
THE DEVIL IN THE DETAILS:

REFLECTIONS ON THE TAX REFORM ACT OF 2014

Reuven S. Avi-Yonah ${ }^{1}$

The Discussion Draft of the "Tax Reform Act of 2014" (TRA14) released by US House Committee on Ways and Means Chairman Dave Camp (R-MI) on February 26, 2014 represents a major effort for fundamental and far reaching reform of US tax law. Unfortunately, while many parts of the proposal seem quite sensible as an effort to bring back the "spirit of 1986", the international tax reform proposals are deeply flawed and based on obsolete assumptions on the world facing US multinationals in 2014.

Overall, TRA14 represents a welcome effort to propose a revenue neutral combination of base broadening and rate cutting. TRA14 envisages three individual rates of $10 \%, 25 \%$ and $35 \%$ and a corporate rate of $25 \%$. This rate structure is quite sensible, and if it can be achieved in a revenue neutral fashion that is an added advantage. ${ }^{2}$

However, the international tax proposals are based on the assumption that because most other OECD countries have adopted a limited version of territoriality, i.e., a "participation exemption" for dividends out of the active income of Controlled Foreign Corporations (CFCs), the US must follow suit to preserve the competitiveness of US based MNEs. But this assumption is wrong, for three reasons. First, the empirical data indicate that under current law US based MNEs do not face a competitive disadvantage despite the fact that they are nominally taxed on a worldwide basis without a participation exemption. ${ }^{3}$ Second, the OECD BEPS project suggests that the effective tax rates of both US and foreign MNEs are headed up, not down. Third and most importantly, reducing the US corporate tax can be done without putting US-based MNEs at a competitive disadvantage even if deferral were completely eliminated, and this has the added advantage of eliminating both lock out (the main problem the participation exemption is designed to solve) and the incentive to shift profits out of the US (which this version of TRA 14 does little to address). Abolishing deferral instead of adopting a participation exemption also does not put domestic US corporations at a competitive disadvantage to US-based MNEs.

This paper will discuss these points and conclude that as far as the international proposals are concerned it would be better to go back to the drawing board and start from scratch with a simple

\footnotetext{
${ }^{1}$ Irwin I. Cohn Professor of Law, the University of Michigan. I would like to thank Jeffery Kadet, Peter Merrill, Fadi Shaheen,Stephen Shay and Bret Wells for very helpful comments.

${ }^{2}$ However, Len Burman has calculated that the marginal effective rate on ordinary income is as high as $67 \%$ because of all the phase outs in TRA14. This rate disparity creates too much of an incentive to convert ordinary income to capital gains or dividends, which are taxed at $23.8 \%$ (including the ACA tax). It would be preferable to reduce the rate on ordinary income and increase the rate on dividends and capital gains.

${ }^{3}$ See Avi-Yonah and Lahav The Effective Tax Rates of the Largest US and EU Multinationals, 65 Tax L Rev 375 (2012); CTJ, The Sorry State of Corporate Taxes (February, 2014).
} 
proposal of full inclusion at whatever corporate rate is judged to be similar to the effective rates paid by foreign-based MNEs.

1. The TRA 14 International Proposals

The TRA14 international proposals are divided into four sections. Title III, Subtitle H (sections 3701-3705) deals with the taxation of foreign persons. Title IV, Subtitle A (sections 4001- 4004) establishes a participation exemption. Title IV, Subtitle B (sections 4101-4104) modifies the foreign tax credit system to reflect the participation exemption. Title IV, Subtitle $C$ (sections 4201-4212) contains modifications to Subpart F and the anti-BEPS rules.

\section{A. Inbound Tax Reforms.}

The inbound tax reforms are quite sensible. Section 3701 eliminates the ability of US insurance companies to avoid tax through reinsuring risks with related companies that are not subject to US income tax, unless the foreign jurisdiction taxes the reinsurance premiums at the US rate or higher. This provision eliminates the ability of companies like UPS to shift premium income from insuring US risks to related foreign corporations that are untaxed. The only question is whether it might be better to tax all insurance companies that insure US risks, as the UN Model tax treaty envisages.

Section 3702 taxes the income of foreign taxpayers derived from the operations of passenger cruise ships within US territorial waters. Over $70 \%$ of those passengers are from the US, and the cruise line companies rely on taxpayer funded US maritime infrastructure and Coast Guard resources. There is no reason to let them avoid tax by flying a Panamanian or Liberian flag.

Section 3703 restricts the insurance exception to the PFIC rules, which is a way for rich US individuals to avoid current taxation on passive income by attaching it to an "insurance company." One should ask whether the problem remains under the insurance exception Subpart F, since a CFC cannot be a PFIC.

Section 3704 reduces the earning stripping ratio from $50 \%$ to $40 \%$ and eliminates carryovers. The same provision should be applied to royalties and cost sharing payments, which can be inflated more easily than interest.

Section 3705 eliminates the lower treaty rate applicable to deductible interest and royalty payments to an entity controlled by a foreign parent if there is no treaty with the parent's residence jurisdictions. This represents a welcome limitation on treaty shopping by, e.g., Brazilian MNEs, and would be an incentive for countries like Brazil to finally enter into a treaty with the US. The provision would presumably represent a treaty override, but one that is consistent with the underlying idea of limitation on benefits. 


\section{B. Participation Exemption.}

Section 4001 establishes a participation exemption by allowing $95 \%$ of dividends paid by a foreign corporation to a $10 \%$ corporate US shareholder to be exempt (whether or not the payor is a CFC). ${ }^{4}$ The $5 \%$ hair cut is in lieu of limits on deductions allocable to exempt income. This provision is estimated to cost $\$ 212$ billion, but as discussed below this may be an underestimate. The rationale is competitiveness and eliminating lock-out, but as discussed below lock-out can be eliminated in other ways without affecting competitiveness.

Section 4002 reduces basis by the amount of exempt dividends, so that no loss would be recognized on a subsequent sale of the stock for the ex-dividend value.

Section 4003 taxes $10 \%$ US corporate shareholders on previously untaxed accumulated E\&P of foreign corporations with $10 \%$ US shareholders at $8.75 \%$ up to the foreign corporation's cash or cash equivalents and 3.5\% for E\&P in excess of that amount. The tax could be paid over 8 years, with no interest charge. The resulting estimated $\$ 126.5$ billion would be devoted to the Highway Trust Fund, which is almost insolvent.

There are about $\$ 2$ trillion of such accumulated low-taxed E\&P, and since it has been earned already and (mostly) not taxed by other countries, why not tax it at the new $25 \%$ rate, or even the current $35 \%$ ? This could generate $\$ 700$ billion in one fell swoop without affecting incentives or competitiveness, thereby closing this year's budget deficit and allowing revenue neutral financing of an extension of unemployment insurance, infrastructure spending, or other one time projects. ${ }^{5}$

Section 4004 makes permanent the 954(c)(6) look through rule for dividends, interest and royalties received by one CFC to another. This is scored as only reducing revenues by $\$ 13.1$ billion, but the true cost is probably higher as discussed below.

\section{FTC Changes}

Section 4101 repeals the indirect credit, which is not needed in the new participation exemption regimes. This would presumably formally override our tax treaties, all of which require the indirect credit, so they will need to be renegotiated. However, section 960 is not repealed, so that there would be an incentive to create Subpart F deemed dividends to

\footnotetext{
${ }^{4}$ Note also section 3661, which eliminates dividends from CFCs from income of personal holding companies subject to an additional $20 \%$ tax to prevent retentions. There is some concern about the treatment of $10 / 50$ corporations, like joint ventures, whose US corporate shareholders benefit from the exemption while not being subject to the anti-BEPS provisions which rely on subpart $F$ inclusions that only apply to CFCs.

${ }^{5}$ Since there does not appear to be a good policy argument against taxing past $E \& P$, this could be done immediately without waiting for tax reform.
} 
benefit from the credits attached to them, especially given the change to the allocation of deductions described below that would increase foreign source income and raise the FTC limit.

Section 4102 removes a definite headache for MNE tax directors by only allocating to foreign source income directly allocable deductions (and not stewardship, general and administrative, and interest expense). This is a welcome simplification of a notoriously complicated area of law, although the interest provision is a significant change (subject to the anti-BEPS rule discussed below).

Section 4103 reconfigures the basket system by creating two baskets, active and mobile, with mobile including current law passive income, certain related party sales income, and foreign intangible income.

Section 4104 eliminates the $50 \% / 50 \%$ allocation of inventory produced in the US for sale overseas; instead, the income is sourced to the location of production. This would seem to discourage production in the US for taxpayers with excess credits, and to benefit foreign importers into the US. TRA14 does not address the more problematic title passage rule for purchased inventory, which should be eliminated as resulting in unwarranted increases in foreign source income for both exporters and importers.

D. Subpart F Modifications and Anti-BEPS Provisions.

Section 4201 excludes from Subpart $F$ income any foreign income subject to the full US tax rate of $25 \%$, except that base company sales income is excluded if it is subject to a $12.5 \%$ tax (as in Ireland) and foreign base company intangibles income is excluded if it is subject to tax at a $15 \%$ rate. These rates are quite low, and it would have been better to include as Subpart $\mathrm{F}$ income any income subject to tax at $15 \%$ or lower (similarly to the requirement of a minimum foreign tax rate in Rep. Camp's original option B and Sen. Baucus' option Y). Allowing the Irish $12.5 \%$ rate to eliminate the application of Subpart $F$ is an invitation to BEPS, as discussed below.

Section 4202 (the "Ireland provision") explicitly excludes from base company sales income any income from a treaty jurisdiction, or any jurisdiction with an effective rate of $12.5 \%$. This allows all the US MNEs that took advantage of the Irish rate to shift profits from both the US and other countries to continue to do so. Moreover, where a CFC earns FBCSI, only $50 \%$ of that income is subpart $\mathrm{F}$ income. The other half, even if subject to zero foreign tax, is eligible for the $95 \%$ participation exemption when the earnings are distributed to its US corporate shareholders.

Section 4203 adjusts the $\$ 1$ million de minimis exception from Subpart F for inflation. 
Section 4204 extends the active financing exception from Subpart $F$ if the income was subject to a $12.5 \%$ effective tax rate, and if the foreign rate is lower the US tax rate would only be $12.5 \%$. This is a boon for US banks and insurance companies with mobile income either in Ireland or in Barbados.

Section 4205 repeals the imposition of current US tax on previously excluded foreign shipping income of a CFC if there is a net decrease in qualified shipping investments.

Section 4211 is the main anti-BEPS provision. It creates a new category of Subpart F income, foreign base company intangible income (FBCII), which is the excess of the CFCs gross income over $10 \%$ of the CFCs adjusted basis in depreciable tangible property. At the same time the CFC gets a deduction for a declining percentage of income (going down from $55 \%$ to $40 \%$ ) from sales of goods and services to foreign customers. The idea is to allow exemption for normal returns to investments in tangible property and to reduce the tax rate on sales to foreign customers to $15 \%$, while preventing base erosion.

This provision is very complex, and has little to do with intangibles. It aims at taxing economic rents from sales primarily into the US, but to some extent to foreign countries as well. However, ultimately $40 \%$ of the rents would be exempt. This complexity is designed to preserve competitiveness but there are far simpler ways of doing so. Moreover, the provision translates into a $15 \%$ tax rate applied to rents from exports but a $25 \%$ rate on rents from imports, which raises serious WTO compatibility issues. The provision only raises $\$ 115.6$ billion over the ten year budget window.

Section 4212 limits the net interest expense of US based MNEs by reducing it by the lesser of (1) the extent to which the indebtedness of the parent exceeds $110 \%$ of the indebtedness of the group, or (2) $40 \%$ of the adjusted taxable income of the parent. This is designed to limit the ability of US-based MNEs to borrow to finance exempt dividends. Excess interest can be carried forward indefinitely. This rule is likewise very complicated and hard to administer, as the German experience with similar rules shows.

2. What about Base Erosion and Profit Shifting?

Under section 4211, a CFC's FBCII is includible in the income of its parents except for $10 \%$ of its basis in tangible property and $40 \%$ of its income from the sale of goods to foreign customers. This is equivalent to a current $25 \%$ tax on sales to the US and $15 \%$ on sales abroad (after reducing the latter income by $10 \%$ of the basis of related tangible property). Under section $4201, \mathrm{FBCll}$ is excluded altogether if it is subject to an effective foreign rate of $15 \%$, and foreign base company sales income is excluded if subject to tax at the Irish $12.5 \%$ rate or if it is earned in any treaty jurisdiction. In addition, active financing income is taxed at $12.5 \%$ (section 4201), and 954(c)(6) (section 4004), which allows for tax-free shifting of profits from one CFC to 
another, is made permanent. The entire proposal thus amounts to taxing CFCs in full on income from sales to the US but at a lower rate (12.5\%-15\%) on sales abroad.

While better than current law which permits effective rates of less than $5 \%$ on the income of CFCs, these provisions, in addition to the participation exemption, are an incentive to shift profits from the US and other higher tax jurisdictions to Ireland and similar countries (for foreign base company sales income and active financing income) or to any jurisdiction with a tax rate of $15 \%$ (for FBCII). There are many countries that would be happy to oblige by setting their rate at $15 \%$, which is why I think there would be greater revenue losses from the exemption and smaller revenue gains from the anti-BEPS provisions than suggested by the official revenue estimates.

If enacted, TRA14 will not please our major trading partners, who are upset by our encouraging BEPS via check the box and 954(c)(6). Retaliation against US-based MNEs is a likely outcome.

Because of these considerations I believe that the international provisions of TRA14 are much worse than Rep. Camp's original proposal and Sen. Baucus' proposal, both of which had more robust anti-BEPS provisions (option B for Camp and option $Y$ for Baucus) and also imposed a higher tax on the \$2 trillion in untaxed offshore income.

3. An Alternative Proposal ${ }^{6}$

In addition, I believe TRA14 is obsolete. Consider the following facts:

a. The nominal tax rate of the $\mathrm{G} 20$ is never lower than $20 \%$ and in most cases is between $20 \%$ and $30 \%$.

b. The effective tax rate of MNEs based in the $G 20$ is close to the nominal rate, even after participation exemptions are taken into account.

c. The $\mathrm{G} 20$ are leading a major anti-BEPS effort in OECD.

Under these conditions, why should the US reward Ireland and other jurisdictions that have a low tax rate by enabling shifting profits to them, when economically these profits are earned in the large developed economies?

Instead, we should simply determine what is the corporate rate that would put US-based MNEs on a level playing field with the $\mathrm{G} 20$, and impose that rate on all future income (past income should be taxed at the full $35 \%$, since that does not affect competitiveness). If the rate is $17 \%$, so be it, as long as it is imposed on both US and foreign income. ${ }^{7}$ Then, we

\footnotetext{
${ }^{6}$ For more details see Avi-Yonah, Hanging Together, available on SSRN.

${ }^{7}$ At $17 \%$ the corporate tax would probably be a revenue loser even if we tax the previously accumulated offshore earnings at $35 \%$, but in the context of TRA14 such a loss can be offset by increasing the rates on dividends and capital gains. Since individuals are less mobile than corporations it makes sense in a globalized world to impose higher tax rates on individuals than on corporations.
} 
negotiate a coordinated tax floor of $20 \%$ or $25 \%$ with the other $\mathrm{G} 20$, who will go along to prevent shifting income into the US. This will be much simpler than the very complex TRA14 anti-BEPS proposals.

This proposal would deal with competitiveness, neutrality, and corporate expatriations at once. Since the vast majority of MNEs are based in the G20, there would be no competitive disadvantage, no violation of CEN, CIN or CON, and no incentive to expatriate, although we should still adopt "managed and controlled" and impose a deemed sale of assets corporate exit tax to prevent corporate expatriations to non-G20 jurisdictions.

TRA14 says that the rationale for departing from the over a century old rule of taxing US resident corporations on all income from whatever source derived is to "allow US companies to compete on a more level playing field against foreign multinationals when selling goods and services abroad" and to "eliminate the "lock-out' effect that results from the US residual tax under current law, which discourages US companies from bringing their foreign earnings back into the United States." ${ }^{8}$ The above proposal would achieve both of these aims while also preventing BEPS and not putting domestic US businesses at a competitive disadvantage compared to US-based MNEs.

\footnotetext{
${ }^{8}$ TRA14 Discussion Draft, Section by Section Summary, at 142 (section 4001).
} 